\title{
Development Model of Basic Technique Skills Training Shot-Put Obrien Style Based Biomechanics Review
}

\author{
Hidayanto Danang Rohmat ; Agus Kristiyanto; Sapta Kunta Purnama \\ Magister Ilmu Keolahragaan, Sebelas Maret University, Indonesia \\ Email: danangrohmat@yahoo.co.id
}

http://dx.doi.org/10.18415/ijmmu.v5i3.253

\begin{abstract}
The background of this research is the unavailability of learning model of basic technique technique of O'Brien style force that integrated in skill program based on biomechanics study which is used as a reference to build the basic technique skill of the O'Brien style force among students. The purpose of this study is to develop a model of basic-style technique of rejecting the O'Brien-style shot put based on biomechanical studies for beginner levels, including basic prefix technique, glide, final stage, repulsion, further motion and repulsion performance of O'Brien style, all of which arranged in a medium that is easily accessible whenever, by anyone and anywhere, especially in SMK Negeri 1 Kalijambe Sragen. The research method used is "Reasearch and Developement" approach. "Preliminary studies show that $43.0 \%$ of respondents considered that the O'Brien style was very important to be developed with a model of skill-based exercise based on biomechanics, as many as $40.0 \%$ ressponden stated that it is important to be developed with biomechanics based learning media. Therefore, it is deemed necessary to develop the learning media of the O'Brien style-based training skills based on biomechanical studies. Development of media starts from the design of the storyboard and script form that will be used as media. The design of this model is called the draft model. Draft models that have been prepared are reviewed by the multimedia expert and the O'Brien style expert to get the product's validity. A total of $78.24 \%$ of experts declare a viable product with some input. In small groups with $n=6$, earned value $72.2 \%$ was obtained or valid enough to be tested in large groups. In the large group test with $n=12$, values obtained $70.83 \%$ or quite feasible to be tested in the field. In the field test, experimental group was prepared with treatment according to media and control group with free treatment. From result of counting of significance test can be interpreted that result of count refuse Ho with count value far above $t$ table value. The results of the basic technique skills of the O'Brien style force increased by $16.0 \%-25.0 \%$ in the experimental group and 2.0\%-19.0\% in the control group. Based on the results of calculating the difference in the final score increase after the final test, showed a greater score difference for the group given the treatment model of the exercise developed by the researcher. Thus it can be concluded that the use of skills-based learning media biomechanics on the model of learning style of O'Brien style can effectively improve the basic technique skills of the style force O'Brien.
\end{abstract}

Keywords: Based biomechanical studies; Basic technique skills; O'Brien shot-put style; R \& D

\section{Introduction}


The trend of using social media becomes a must for adolescents to follow it, so it is not surprising with the number of television programs and the proliferation of television stations make the children more enjoy to sit in front of the television and play mobile phones. The existence of the changes above is an important signal to look for alternative solutions. From such conditions, finally educational practitioners think hard to formulate a new paradigm in education. Implementation of full day school is one alternative to overcome various problems of education, both in achievement and in terms of morals or morals. By attending full day school, parents can prevent and neutralize the likelihood of children's activities plundering on negative activities. One of the reasons parents choose and put their children into full day school is in terms of student education (Bahruddin., 2010: 230).

Physical education is part of education as a whole. In the implementation of physical education tailored to the objectives to be achieved. According to Nadisah (1992: 15) suggests that physical education of sports and health is part of education (in general) that goes through activities that involve the mechanisms of human body movement and generate patterns of individual behaviors concerned.

According to Engkos Kosasih (1992: 4) suggests that physical education of sports and health is education that actualizes the potential of human activities in the form of acts and actions to be given form, content and direction towards personality roundness in accordance with the ideals of humanity. The Physical Education is a process of education that utilizes physical activity and is planned systematically aimed at increasing individuals organically, neuromuscularly, perceptually, cognitively, socially and emotionally.

Schools other than as formal educational institutions, can also serve as a place of development and sports coaching. Evidenced by the inclusion of athletic sports into the school curriculum, from elementary school to high school kejuruaan provide a positive impact in the world of education, in the development of athletic sports into a popular sport in Indonesia, especially on the throwing numbers, Indonesian athlete Eki Febri Ekawati won medals gold SEA Games 2017 at Bukit Jalil Stadium, Kuala Lumpur, Malaysia, from a shot put with O'Brien style with 15.39 meters repulsion performance. This extraordinary achievement of course requires hard training.

Learn about the O'Brien style starting force from the ground level. At this stage, as a core exercise student learns basic engineering movements. Basic motion exercises or basic techniques of the O'Brien style, students must understand movement techniques properly and correctly so that students must really understand the basic techniques and concepts. Mastery of good basic techniques will provide an optimum blast effect. To be able to master good basic engineering skills requires regular and thorough training. Exercise can be done at school according to the curriculum applied in school. Given the limitations of school hours and the considerable curriculum content of the lesson, the exercises can be done on self-development activities outside the learning hours. In addition, training can also be done at home or at other places at any time and every opportunity. Because this basic technique training technique, the o'brien style requires accuracy in both techniques and trajectories, there needs to be guidance, direction and monitoring from teachers, instructors or trainers. The problem that then arises is, first the limitations of face to face does not allow teachers to monitor continuously the development of students' abilities, the second is the absence of practical learning media for the competence of the shot hit. The concept of learning that is currently being developed is active, initiative, creative, effective and fun learning. Of course, this requires that the concept developed can foster student involvement. So, without realizing directly by the students turns out students have been involved in a deep and deep in the learning process.

Many factors that affect student learning outcomes, one of which is a problem in learning activities. The causes of learning problems can be sourced from internal and external factors such as 
student motivation and enthusiasm of learning materials. While external factors include the family and the surrounding environment that can be teachers, environment, materials, media and methods used by teachers. Lack of student participation in following the lesson will reduce the success rate of students in learning. Therefore, it is necessary to take action that is able to involve the active role of students in following the learning to achieve the learning objectives, the development of model of basic technique skills exercise based on O'Brien biomechanics study is expected to be one alternative to improve student achievement and learning outcomes. In addition, there is an increase in the number of students who participate in the learning both in the classroom and in extracurricular activities held in schools as well as groups of athletic associations outside school.

\section{Methodology}

This research method using Research and Development approach. While the selected research development model is an educational research and development model developed by Borg and Gall. According to Borg and Gall (1989: 772), "educational research and development (R \& D) is a process used to develop and validate educational production". In that sense, the series of steps of research and development is carried out cyclically, and at every a step that will pass or do always refer to the results of previous steps until eventually obtained an educational products.

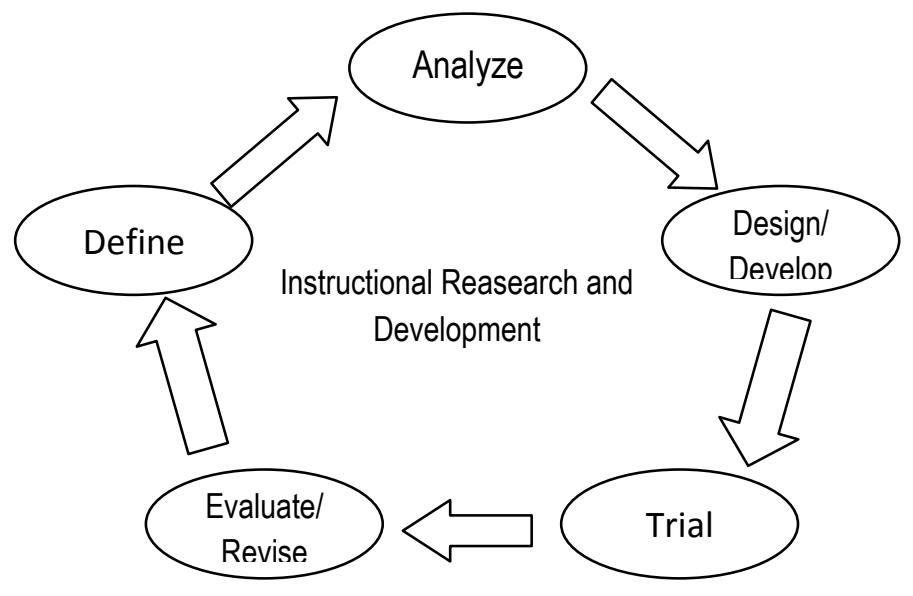

Fig 1. Model development cycle Borg and Gall (1989: 782)

As described in the previous discussion of research model development Borg and Gall covers ten steps as follows: 1) Preliminary Study, 2) Planning research, 3) The development of the initial product, 4) The field trials early (limited), 5) Revision field test results is limited, 6) field test broader, 7) Revision field test results, 8) test the feasibility, 9) Revised results of due diligence, 10) dissemination and socialization of the final product.

The design of material substance and production of learning media follows the procedure developed by Hackbarth, (1996: 178), namely: Material selection, material writing, organizing the content, storyboarding, detailed script writing based on complete storyboard, test and script repair.

The design of skills model based on biomechanical study involves several elements of the developer of personnel who served as the designer of content/ material, vidio takers, images and computer 
programming experts. The expert sources involved in designing and manufacturing this research product are product designers, O'Brien style experts, vidio takers, images, image editors, vidio editors, script makers, and computer programming experts. The production of the product remains in the control of the researcher as the principal product designer so that the expert resource involved only acts as a technical and consultant.

Sample selection in this research for product testing is done by purposive because it is known its characteristics. According to Maksum (2009: 44) "purposive sampling is a sampling technique whose characteristics or characteristics are known in advance based on the characteristics or nature of the population." To facilitate in analyzing the data without having to distinguish the sex then in this study selected a sample of male sex -lites. In this case selected class X TKR. Then the next by way of random sampling because the sampling is done randomly.

Maksum (2009: 41) states "random sampling is a sampling technique that provides equal opportunities for individuals who become members of the population to be elected as a sample member." In this study sampling as a research subject is a student class X TKR, then taken at random without choose according to the levels and the age limit. The number of samples taken in this study were 31 male students from a total of 103 students. Details of the sample in this development study are as follows: 1) Test small group using 6 samples. 2) Large group tests used 12 samples. 3) Product effectiveness test: the experimental group used 12 samples, the control group used 12 samples.

\section{Result and Discussion}

Preliminary stage in this research is the analysis of the need to identify the problem, in this study needs analysis done using the facilities through the online questionnaire https://docs.google.com is distributed via facebook account. There were 40 respondents who responded with $97.4 \%$ of whom were teachers/ lecturers PE. The following detailed data questionnaire count results.

From the calculation results can be interpreted bahrwa significance test, test data obtained from one or more subjects misses. All indicate that the results of the count reject Ho with a calculated value that is far above the value of $t$ table. All showed the results of a significant increase due to the increase in the results of the basic technical skills of martial arts increased by approximately $20 \%-30 \%$ only. It is based on the calculation results increase the final score difference after performed the final test which showed the difference in scores is greater for a given treatment group training models developed by researchers.

\section{Conclusion}

Product development model Basic technique training technique of O'brien style shot-based force based on biomechanical study based on test results of significance to the experiment can be concluded can improve Achievement and mastery of basic technique of starting style bulletin style O'Brien at SMK Negeri 1 Kalijambe Sragen effectively and efficiently. This is based on the result of calculating the difference in the final score increase after the final test which showed a greater score difference for the group given the treatment model of the exercise developed by the researcher.

\section{Suggestion}


1. For Students: students are expected to pay close attention to the contents as well as giving instructional materials on basic technique skills of the O'Brien style wielding force based on biomechanical studies.

2. For Teachers: the use of interesting learning media and can motivate students should always be developed in order to better motivate students to explore themselves tminat and about his own talent and can be developed toward achievement.

3. For Researchers: who will develop the learning model of O'Brien's style of reject should pay attention to the various learning approaches to be more interesting as well as combinations of sports learning models to avoid boredom and boredom in exploring the talent of the sport it has.

\section{References}

Baharudin. (2010). Teori Belajar dan Pembelajaran. Jogjakarta: AR-Ruzz Media.

Borg, W. R. \& Gall, M. D. Gall. (1989). Educational Research: An Introduction, Fifth Edition. New York: Longman.

Depdiknas. (2006). Kuriulum Tingkat Satuan Pendidikan (KTSP). Jakarta: Departemen Pendidikan Nasional.

Engkos Kosasih. (1984). Olahraga Teknik dan Program Latihan. Jakarta. Akademika Presindo.

Hackbarth, S. (1996). The Educational Technology Handbook a Comprehensive Guide. Educational Technology Publications. Englewood Cliffs. New Jersey.

Maksum, Ali. (2009). Metode Penelitian dalam Olahraga. Surabaya: Fakultas Ilmu Keolahragaan. Universitas Negeri Surabaya.

\section{Copyrights}

Copyright for this article is retained by the author(s), with first publication rights granted to the journal.

This is an open-access article distributed under the terms and conditions of the Creative Commons Attribution license (http://creativecommons.org/licenses/by/4.0/). 